\title{
Guillain-Barré syndrome and Zika virus infection
}

\section{Síndrome de Guillain-Barré e infecção pelo Zika vírus}

Dear Editor, the recent article on "Guillain-Barré syndrome (GBS) and Zika virus infection? is very interesting ${ }^{1}$. Araujo et al. noted that "the incidence of GBS has increased in Brazil since 2015, what is speculated to be secondary to the Zika infection outbreak ${ }^{1}$." Araujo et al. ${ }^{1}$ also noted that "The diagnosis of GBS is feasible even in resource-limited areas using the criteria proposed by the GBS Classification Group, which is based solely on clinical grounds." In fact, GBS is an important possible complication of Zika virus infection ${ }^{2}$. However, there are some concerns. First, the first identification of the possible interrelationship between GBS and Zika virus infection has just been proposed. There has never been previous observation despite there were many previous big outbreaks in the Pacific region. The next concern is on the rate of GBS. The question is there any poofs that there is no other cause that can induce GBS. On the other hand, since the Zika virus infection can be a silent infection and under diagnosed ${ }^{3}$, hence, some GBS cases relating to Zika virus infection might be under diagnosed. The Zika virus infection and its consequence, GBS, might be more common than expectation.

Viroj Wiwanitkit

\section{References}

1. Araujo LM, Ferreira ML, Nascimento OJ. Guillain-Barré syndrome associated with the Zika virus outbreak in Brazil. Arq Neuropsiquiatr. 2016;74(3):253-5. doi:10.1590/0004-282X20160035

2. Cao-Lormeau VM, Blake A, Mons S, Lastère S, Roche C, Vanhomwegen $J$ et al. Guillain-Barré syndrome outbreak associated with Zika virus infection in French Polynesia: a case-control study. Lancet. 2016;387(10027):1531-9. doi:10.1016/S0140-6736(16)00562-6

3. Wiwanitkit S, Wiwaitkit V. Afebrile, asymptomatic and non-thrombocytopenic Zika virus infection: Don't miss it! Asian Pac J Trop Med. 2016;9(5):513. doi:10.1016/j.apjtm.2016.03.036 